\title{
Hadis dan Politik Sektarian: Analisis Basis Argumentasi tentang Konsep Imamah Menurut Shì'ah
}

\author{
Andi Rahman ${ }^{1}$
}

\begin{abstract}
This article discusses and analyzes the basic reading and argumentation of the Shi 'ite over the issue of political leadership in Islam, compared with that existing in the Sunnite conception. It discusses their argumentation based on their textual and contextual understanding of the Qur'an and Hadith. Sunnites and Shi'ites have different opinion over whether Islamic leadership are set based on appointment (imāmah) or election (khilāfah).
\end{abstract}

\begin{abstract}
Abstrak
Tulisan ini membaca dan menganalisis basis argumentasi Shī'ah terkait isu kepemimpinan politik dalam Islam, dikomparasikan dengan konsepsi yang ada di Sunni.

Tulisan ini mendiskusikan argumentasi mereka yang muncul berangkat dari pemahaman tekstual dan kontekstual terhadap teks al-Qur'ān dan hadith. Sunni dan Shi' 'ah berbeda pendapat terkait apakah pemimpin umat Islam ditetapkan berdasarkan penunjukan (imāmah) atau pemilihan (khilāfah).
\end{abstract}

Keywords: Khiläfah, Imāmah, Manzilah, dan Thaqalayn.

\section{Pendahuluan}

Perpepecahan pertama yang terjadi di antara umat Islam, adalah masalah politik. $^{2}$ Sejarah mencatat bahwa jasad Rasulullah belumlah dimakamkan, umat Islam sudah berselisih tentang siapa yang akan menggantikan beliau sebagai pemimpin mereka. Peristiwa di Saqifah Bani Sāidah yang terekam dalam riwayat hadis dan literatur sejarah digambarkan berlangsung panas dan

\footnotetext{
${ }^{1}$ Dosen Institut PTIQ Jakarta, E-mail: andiwowo@yahoo.com

${ }^{2}$ Ahmad Ibrāhīm Hamūr, Shadhrat min Tärỉkh al-Daulah al-Umawiyah fi al-Sharq (Cairo: Dàr al-Ṭibā'ah al-Muhammadiyah, 1998), cet. IV, 115.
} 
mencekam. ${ }^{3}$ Hampir saja bangunan kesatuan umat Islam yang selama bertahuntahun diupayakan untuk bersatu oleh Rasulullah, runtuh dalam satu hari. ${ }^{4}$

Belakangan, perbedaan preferensi politik terkait siapa yang paling berhak menggantikan Rasulullah dalam tugasnya memimpin umat Islam, mengkristal dalam mazhab (sekte) Shì' ah dan Sunni. Masing-masing mazhab ini memiliki landasan argumentasinya yang dibangun berdasarkan intepretasi nash dan nalar logika.

Asumsi bahwa kemunculan sektarian dalam teologi Islam diawali dengan perdebatan politik, ditolak oleh sebagian orang. Muhammad al-Musawi secara tegas menyatakan bahwa Shi' ah bukanlah mazhab politik. Hal senada juga dinyatakan oleh Seyyed Hossein Nasr, bahwa kemunculan Shi' ah bukan semata didasari masalah politik, utamanya masalah sosok penerus Rasululah dalam memimpin umat Islam. ${ }^{5}$

\section{Islam dan Wacana Suksesi Kepemimpinan}

Diskursus yang ada di kalangan umat Islam mengenai hubungan antara Islam dan sistem ketatanegaraan, memunculkan tiga pendapat: Pendapat pertama berpendirian bahwa Islam adalah agama sempurna dan paripurna yang mengatur segala aspek, termasuk politik. Pendapat ini dianut oleh Hasan alBannā, Sayyid Quṭb, Rashīd Ridhā dan al-Mawdūdi. Menurut mereka, umat Islam harus menggunakan sistem perpolitikan ilahiyah. Umat Islam dilarang meniru sistem ketatanegaraan Barat. ${ }^{6}$

Pendapat kedua menyatakan bahwa Islam itu agama sekuler, yang dipahami dalam terminologi yang berkembang di Barat. Islam hanya mengajak

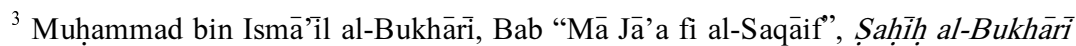
(Dār Ṭūq al-Najāh, 1422 H), cet. I, vol. I, hlm. 132, juga pada Bab "Qawl al-Nabi Law Kuntu Muttakhidzan Khalilan", vol. V, 6.

${ }^{4}$ Ketika Rasulullah wafat, ada banyak shahabat yang berkabung dan mengalami kegugupan. Shahabat-shahabat dari golongan Anșār menyadari bahayanya kekosongan kekuasaan, mengingat kamu muslimin sedang berknfrontasi dengan imperium Romawi. Mereka berkumpul di kabilah Bani Sä'idah untuk mengangkat orang yang menjadi pimpinan politik umat Islam. Mereka hampir mengangkat Sa'd bin Muā'dz sebagai khalifah hingga akhirnya Abū Bakar bersama 'Umar bin al-Khatạ̄b dan Abū 'Ubaydah menemui mereka. Setelah mengalami perdebatan yang sengit, dengan disertai bayangan disintegrasi politik, Abū Bakar terpilih sebagai khalifah.

5 Muhammad al-Musawi, Mazhab Pecinta Keluarga Nabi Kajian Al-Quran dan Sunnah (Bandung: Mpress, 2009), cet. III, 61.

Muhammad Husayn Thabathaba'i, "Kata Pengantar" dalam Islam Syiah Asal Usul dan Perkembangannya (Jakarta: Pustaka Utama Grafiti, 1993), cet. II, 8.

${ }^{6}$ Salah satu dalil penganut mazhab ini adalah ayat 50 surah al-Maidah, "Apakah mereka condong kepada hukum jahiliyyah. Tidak ada yang lebih baik dari pada hukum Allah, bagi kaum yang memiliki keyakinan (beriman)." 
umat manusia kepada kemuliaan hidup dan keluhuran budi pekerti, bukan alat kekuasaan. Rasulullah adalah utusan Tuhan, bukan kaisar yang memiliki visi politik. Kehidupan sosial dan politik umat Islam diserahkan kepada mereka, tanpa campur tangan Agama yang bersifat normatif dan mengikat. Pendapat ini dianut oleh 'Ali 'Abd al-Rāziq dan Ṭaha Husain. ${ }^{7}$

Pendapat ketiga menolak teokrasi Islam sekaligus sekulerisme Barat. Pendapat ini berupaya bersikap moderat yaitu bahwa Islam tidak mengajarkan sistem ketatanegaraan tertentu, namun di waktu yang sama ia memiliki seperangkat tata nilai dan etika yang bisa digunakan dalam kehidupan berpolitik dan bernegara. Umat Islam bebas memilih dan menerapkan sistem dan bentuk negara dan pemerintahan yang sesuai dengan konteks zaman dan tempatnya masing-masing. Muḥammad Husain Haikal adalah salah seorang pendukung pendapat ini. ${ }^{8}$

Kemudian, para cendekiawan muslim dengan berbagai sektenya mengategorikan konsepsi pemilihan kepala negara dalam dua macam: Imāmah yang ditetapkan berdasarkan penunjukan oleh nash, dan khilāfah yang dilakukan melalui mekanisme pemilihan (shūrā). ${ }^{9}$

Pendapat pertama disokong oleh golongan Shì'ah Imāmiyah (Ithnā 'Asyariah), Jārūdiyah, serta Rawandiyah Abbasiyah, yang menyatakan bahwa imāmah atau kepemimpinan adalah prinsip dasar dalam Islam yang tidak mungkin diabaikan. Menurut mereka, ketika masalah sehari-hari yang tidak menyangkut kepentingan dan hajat hidup orang banyak telah digariskan ketentuannya oleh agama, maka sudah semestinya Rasulullah secara eksplisit dan implisit memberikan ketetapan siapa yang akan menjadi penerus beliau sebagai pemimpin umat. Golongan yang mendukukung pendapat ini meyakini bahwa Rasulullah telah memberi wasiat kepada 'Ali bin Abū Tāalib untuk menjadi penggantinya. Wasiat ini selanjutnya berlaku untuk keturunan 'Ali bin Abū Tạalib.

7 Dalam banyak tempat, Alquran menyatakan bahwa Rasulullah Muhammad hanyalah merupakan orang yang menyampaikan peringatan (nadhir), misalnya QS. AlA'rāf: 188, Hūd: 12, Hajj: 49, al-Syuā'arā: 115, al-'Ankabūt: 50, Sabā: 46, Fātir: 23, Shād: 70, al-Ahqāf: 9, dan al-Mulk: 26.

${ }^{8}$ Lihat: Munawir Sjadzali, Islam dan Tata Negara: Ajaran, Sejarah dan Pemikiran (Jakarta: Penerbit Universitas Indonesia (UI-Press), 1993), 1-2.

${ }^{9}$ Kata "shūrā" atau "musyawarah" berasal dari bahasa Arab, dan nampaknya tidak ada perbedaan substantif antara pemaknaannya dalam bahasa Arab dan bahasa Indonesia, yaitu bermusyawarah. Dalam ranah politik nasional Indonesia kontemporer, kata dewan syuro (shūrā) sudah lazim digunakan sebagai nama lambaga tertinggi di beberapa partai politik yang berbasiskan umat Islam. 
Berbeda dengan Shi'ah, Sunni mengusung pendapat kedua yang menyatakan bahwa klaim wasiat ini tidak benar, dan bahwa sesungguhnya Rasulullah tidak pernah menetapkan secara definitif sosok orang yang akan menggantikannya sebagai pemimpin politik bagi umat Islam. Riwayat-riwayat yand terkait wasiat kepada 'Ali dinilai tidak shahih, ditakwilkan, atau dipahami secara kontekstual. Riwayat yang valid terkait masalah kepemimpinan Umat Islam, menurut Sunni, adalah bahwa Rasulullah hanya memberikan kriteria orang yang bisa (dan boleh) dipilih (diangkat) sebagai pemimpin.

Menurut Sunni, shūrā bukan sekedar prosedur dan mekanisme yang direkomendasikan, tetapi merupakan perintah. Rasulullah sebagai manusia yang disinari wahyu Ilahi, senantiasa melakukan shürā sebelum menetapkan sebuah kabijakan sosial dan politis. Hal ini nampaknya dimaksudkan sebagai pengajaran dan pengejewantahan dari sistem shūrā yang diajarkan al-Quran. ${ }^{10}$

Walau sedemikian besar anjuran untuk melakukan shūrā, namun Sunni menegaskan bahwa tidak semua hal dapat dishürākan, misalnya doktrin akidah yang sudah berada di luar "kewenangan" manusia. Jika materi seperti Rukun Iman dan Rukun Islam dimusyawarahkan, hal ini bisa berakibat kepada kekufuran dan bid'ah/heretisme.

Dalam menguatkan basis penolakannya terhadap penunjukan 'Ali bin Abū Ṭālib sebagai khalifah, Sunni memaparkan data sejarah bahwa 'Ali yang menganggap dirinya orang yang paling berhak menduduki kekhilafahan pasca kemangkatan 'Umar, tetap berkenan mengikuti mekanisme shürā bersama 6 orang shahabat lain. Saat kecenderungan tim formatur menuju kepada pengangkatan 'Uthmān, 'Ali berkata bahwa dirinya dan seluruh ahl al-bait adalah buah, sementara Quraish adalah pohonnya. Buah adalah sebaik-baik apa yang ada di dalam pohon. ${ }^{11}$ Namun ketika ternyata ia tidak terpilih, Ali bersikap legawa dan menyatakan dukungannya.

\section{Khilafah Versus Imamah}

Khilāfah atau khalifah secara etimologis bermakna "(orang yang) berada di belakang". Kata ini kemudian identik dengan makna kepemimpinan umat, seperti ungkapan yang dipakai nabi Mūsā saat menjadikan nabi Hārūn sebagai

${ }^{10}$ Allah berfirman dalam al-Shūrā ayat 8 , "Dan (bagi) orang-orang yang menerima seruan Tuhannya dan mendirikan shalat, sedang urusan mereka (diputuskan) dengan musyawarah di antara mereka” Firman-Nya dalam Âlu Imran ayat 159, “...Karena itu maafkanlah mereka, mohonkanlah ampunan untuk mereka, dan bermusyawarahlah dengan mereka dalam urusan itu..." Sharq, 117.

1 Ahmad Ibrāhīm Hamūr, Shadhrat min Tărīkh al-Daulah al-Umawiyah fi al- 
pemimpin sementara bagi Bani Israil selama dirinya melakukan mīqü. ${ }^{12}$ Orang yang mengemban misi khilāfah disebut khalifah.

Imāmah sebagai pembanding dari khilāfah, menurut etimologi bermakna "menjadi pelindung atau panutan" yang kemudian juga identik dengan kepemimpinan, karena pemimpin adalah orang yang pelindung yang dianut. Kata ini bersifat netral di mana dapat diasosiasikan positif ${ }^{13}$ dan negatif. ${ }^{14}$

Orang yang memperoleh mandat imāmah disebut imām. Kata imām bisa disandangkan secara hakiki (denotatif), dapat juga dipahami secara majazi (metafor/konotatif). Misalnya ungkapan bahwa "al-Qur'ān adalah imām bagi kaum muslimin" karena al-Qur'ān memuat ajaran dan tata nilai yang harus dijadikan pedoman dan anutan. Abu Zahrah menyamakan antara imāmah dengan khilāfah. ${ }^{15}$ Selain kata imām dan khalifah, umat Islam juga mengenal kata amir, ${ }^{16}$ malik, raīs, dan sultān sebagai julukan bagi pemimpin politik

12 Dalam surah al-A'rāf ayat 142 Allah Ta'ala berfirman, “...Dan berkata Musa kepada saudaranya yaitu Harun: Gantikanlah aku dalam (memimpin) kaumku..."

${ }^{13}$ Dalam surah al-Baqarah ayat 124 Allah Ta'ala berfirman, “...(Allah) berfirman: Aku akan menjadikanmu imam bagi seluruh manusia...” Juga dalam surah al-Anbiyā ayat 73, "Dan telah Kami jadikan mereka sebagai pemimpin-pemimpin yang memberi petunjuk dengan perintah Kami..."

${ }^{14}$ Dalam surah al-Tawbah ayat 120 Allah Ta'ala berfirman, “...Maka perangilah pemimpin-pemimpin orang kafir itu..." Juga dalam al-Qașaș ayat 41, "Dan telah Kami jadikan mereka pemimpin-pemimpin yang menyeru (manusia) ke neraka. Dan pada hari Kiamat mereka tiadalah ditolong".

15 Ali Ahmad al-Salus, Imamah dan Khilafah dalam Tinjauan Syar'i (Jakarta: Gema Insani Press, 1997), cet. I, 14.

${ }^{16}$ Istilah amīr berasal dari kata imārah. Kata ini bersama imām dan khalifah dalam ranah politik sering dipahami sebagai sinonim. Dalam tinjauan historis, sebenarnya istilah amir telah ada lebih dahulu dari pada sitilah khalifah atau imām. Sejarah mencatat bahwa dalam pertemuan Saqiifah Bani Sāidah, kaum Anșār pada awalnya menghendaki adanya keamiran di kalangan mereka yang terpisah dari keamiran kaum Muhäjirin. Kaum Anșār menawarkan opsi mengangkat amīr dari pihak mereka sendiri sementara Muhājirin dipersilahkan melakukan hal yang sama. Namun Abū Bakar mengingatkan bahwa keamiran berada di tangan orang-orang yang berasal dari suku Quraish yang nota benenya adalah golongan Muhājirin, sementara kementerian (wizārah) menjadi bagian yang diisi oleh golongan Anșār.

Penggunaan titel Amir al-mukminin sebagai panggilan bagi pemimpin politik tertinggi di kalangan umat Islam, pertama kali diberlakukan pada masa 'Umar bin alKhațāb, karena penggunaan titel "khalifahnya khalifah Rasulullah" baginya terasa menyusahkan, apalagi bagi orang yang akan menjadi khalifah sesudahnya akan mendapat julukan "khalifahnya khalifah dari khalifah Rasulullah. Semakin ke belakang, semakin banyak kata "khalifah" yang digunakan, sehingga nampaknya titel amir al-mukminin lebih memudahkan. Namun, dengan penelusuran lebih lanjut, kita dapati bahwa pada zaman Rasulullah, titel ini sudah digunakan, tepatnya saat Rasulullah mengutus Abdullah bin Jahsh bersama 12 orang dari shahabat Muhajirin ke tempat yang bernama Nakhlah pada bulan Rajab 17 bulan setelah peristiwa Hijrah. Rasulullah menjulukinya "Amirul mikminin:. 
mereka. Namun dalam diskursus teologi, istilah imām dan khalifah lebih dominan dan lebih sering digunakan.

Kelompok Sunni menilai institusi khilāfah dan imāmah memiliki fleksibilitas yang signifikan, di mana terkadang seorang khalifah di waktu yang sama ia juga mendapat panggilan khalifah, imām dan amīr al-mukminīn, misalnya 'Ali bin Abū Ṭālib. Hal serupa dilakukan 'Ubaidullāh al-Mahdi, pendiri dinasti Fātimiyah, yang menyebut dirinya amìr al-mukminin di samping khaTifah al-muslimin dan imām al-millah.

Dalam catatan sejarah penggunaan tiga istilah khalifah, imām dan amir seringkali mengalami pergeseran. Misalnya pada masa dinasti Umayah, istilah "amīr" disandang oleh pemimpin provinsi. sementara pada pemerintahan Saljūk, Ayyūbiyah dan Mamlūk di Mesir para pejabat militerlah yang mendapat julukan amir.

Hal ini berbeda dengan Shi' ah yang memahami imamah secara dogmatis dan tidak berubah sampai sekarang. Shì'ah memahami bahwa imāmah yang selamanya memiliki dimensi spiritual dan politis. Sifatnya yang sakral menjadikannya bukan jabatan politis yang dapat ditetapkan melalui mekanisme pemilihan. Imāmah adalah salah satu Rukun Iman yang tidak mungkin dilupakan oleh Rasulullah untuk disampaikan kepada umatnya.

Teori imāmah memang identik dengan Shī'ah, namun demikian golongan Sunni juga menggunakan gelar ini. Ada asumsi bahwa Sunni menghendaki pengaburan makna imāmah yang ada di kalangan Shì'ah, dengan cara mempararelkannya dengan gelar amïr dengan gelar khalifah atau gelar lainnya bagi seorang pemimpin.

\section{Basis Argumentasi Imāmah}

Doktrin Shī'ah menyatakan bahwa basis Islam bersandar pada sejumlah prinsip, di mana yang paling penting adalah al-wilayah (kekuasan politik). Menurut Muhammad al-Baqir, konsep al-wilāyah ini lebih penting dari shalat, zakat, haji, dan puasa. ${ }^{17}$ Nampaknya ada semacam ijma' di kalangan Shī'ah

Lihat Ibn al-Qayyim dalam $Z \bar{a} d$ al-Ma'ād, sebagaimana dikutip oleh Abdul Fattah Abu Ghuddah dalam Umarā al-Mu'mininn Fi al-Hadith (Aleppo: Maktabah al-Matbu'àt al-Islāmiyah, $1411 \mathrm{H}$.), cet. I, 137.

Adapun penggunaan titel imām, nampaknya baru berlaku pada masa 'Ali bin Abū Tạalib.

Lihat: Aḥmad Ibrāhīm Ḥamūr, Shadhrat min Tärīkh al-Daulah al-Umawiyah fi alSharq, 144 .

${ }^{17}$ Muhsin Qiraati, Ushuluddin (Lesson From Al-Qur'an) (Jakarta: Penerbit Cahaya, 2007), cetakan khusus, 355. 
(imāmiyah) bahwa imāmah dan konsep al- 'adl menjadi sumber utama perangkat yurisprudensi hukum dan politik bagi umat Islam. ${ }^{18}$

Imāmah menjadi doktrin utama dalam Shì'ah (Imāmiyah/Ithnā 'Asyariyah) didasari oleh dalil-dalil tentang keutamaan 'Ali bin Abū Ṭālib dan keturunannya serta ayat dan hadis tentang wasiat (wasiyah), manzilah, thaqalayn, dan kewajiban memiliki imām.

\section{A. Cinta Terhadap Rasulullah dan Ahlul Bayt}

Sunni maupun Shi'ah sepakat bahwa 'Ali bin Abu Ṭālib dan keturunannya merupakan manusia yang mulia. Kemuliaan ini diperoleh karena mereka memiliki hubungan darah dengan Rasulullah, dan bahwa mereka ditunjuk oleh Allah Ta'ala sebagai pemimpin umat Islam. 'Ali bin Abū Ṭālib menjadi suami dari Fạtimah ${ }^{19}$ putri Rasulullah, sekaligus merupakan kerabat beliau. 'Ali mendapat didikan langsung dari beliau, sehingga ia dianggap paling layak melanjutkan kepemimpinan umat Islam setelah kemangkatan Rasulullah.

'Ali bin Abū Ṭālib termasuk orang pertama yang masuk Islam. Ia adalah orang yang sangat dekat dengan Rasulullah dan menjadi kepercayaan beliau. Dalam beberapa riwayat dinyatakan secara tegas bahwa 'Ali dicintai Allah dan Rasul-Nya dan ia mencintai keduanya. ${ }^{20}$ Ada riwayat yang menyatakan bahwa 'Ali dilindungi dari kesalahan (dosa), dan apapun yang dilakukannya atau diucapkannya sepenuhnya sejalan dengan ajaran agama Islam. Sosok pemberani ini disebut sebagai orang yang paling mengetahui ilmu-ilmu Islam dan hukum Islam (aqụ̄kum). Manāqib (riwayat kebaikan) 'Ali sangatlah banyak, dan tidak sedikit kitab dan buku yang ditulis khusus tentang keutamaannya. ${ }^{21}$

${ }^{18}$ AA Sachedina, Kepemimpinan Dalam Islam Perspektif Syi' ah (The Just Ruler in Shi' ite Islam) (Bandung: Penerbit Mizan, 1994), cet. II, 21.

${ }^{19}$ Fathimah dijuluki sebagai "ummu abiha" atau ibu bagi ayahnya, karena beliaulah yang secara intens mengurus Rasulullah pasca wafatnya Khadijah. Dalam banyak riwayat disebutkan bahwa Fathimah adalah orang yang paling mirip dengan khadijah (ibunya) dan orang yang laing dekat dengan Rasulullah.

20 "Rasulullah bersabda: Akan aku berikan panji perang besok hari kepada laki-laki yang dicintai Allah dan Rasul-Nya atau mencintai Allah dan Rasul-Nya. Laki-laki ini akan membawa kemenangan. ...kemudian Rasulullah memberikan panji itu kepada 'Ali bin Abū Ṭălib..."

Al-Bukhārī, Bab "Mā Jā'a fi Liwā al-Nabi", Sahịh al-Bukhârīi, vol. IV. 54.

Muslim bin al-Hajjaj, Bab "Min Fạ̣̄'il 'Ali”, Șaḥīh Muslim (Beirut: Dār Ihyāa alTurāth al-'Arabi), vol. IV, 1872.

${ }^{21}$ Al-Nasā'i sebagai salah satu kolektor hadis kenamaan dalam sekte Sunni (dan juga Shi' 'ah) mengumpulkan hadis-hadis tentang keutamaan 'Ali dalam kitab Khașäiṣ 'Ali. Dalam kitab-kitab hadis Sunni lainnya semisal Sahịhh al-Bukhāri dan Saḥịh Muslim ada bab khusus tentang keutamaan-keutamaan (fậá’il/manāqib) 'Ali bin Abù Ṭàlib. 
Beberapa ayat al-Qur'ān ditafsirkan oleh sebagai pujian dan penjelas luhurnya kedudukan 'Ali bin Abū Ṭālib, misalnya kata "khayr al-bariyyah" pada surah al-Bayyinah. ${ }^{22}$ Sebagai salah seorang sahabat Rasulullah yang mulia, mencintai 'Ali bin Abū Ṭālib dinilai sebagai salah satu ciri keimanan, dan siapapun yang membencinya bisa dikategorikan sebagai munafik. ${ }^{23}$

Diskursus tentang siapa yang lebih utama di antara shahabat Rasulullah, utamanya antara Abū Bakar dan 'Umar bin al-Khațāb dengan 'Ali bin Abū Ṭālib, merupakan masalah yang diperselisihkan. ${ }^{24}$ Masing-masing pendapat bisa dibenarkan. Karena termasuk kategori furü'iyyah, mengutamakan satu shahabat atas shahabat lain tidak berpengaruh terhadap keimanan, sebagaimana mengutamakan seorang nabi atas nabi lainnya juga tidak berpengaruh kepada keimanan.

Sunni dan Shī'ah memiliki kesamaan pendapat, di mana menurut kedua sekte ini seluruh umat Islam sudah seharusnya mencintai Rasulullah dan keturunan beliau yang dikenal dengan sebutan ahlul bayt. ${ }^{25}$

Para penafsir al-Quran menyatakan bahwa kata ahlul bayt disebutkan dalam ayat 33 surah al-Ahzab ${ }^{26}$ adalah 'Ali, Fạtimah, dan kedua anak mereka. Saat ayat ini diturunkan, Rasulullah mengambil sorbannya dan mengalungkan dirinya bersama empat orang tersebut seraya menyatakan bahwa orang-orang

${ }^{22}$ Firman Allah Ta'ala dalam surah al-Bayyinah ayat 7, "Sesungguhnyaorangorang yang beriman dan beramal shaleh, mereka itulah sebaik-baik makhluk". Disebutkan bahwa 'Ali bin Abū Țâlib sering dipanggil sebagai khair al-bariyyah oleh Rasulullah dan para shahabatnya. Dalam beberapa riwayat dinyatakan bahwa titel ini berlaku bagi 'Ali bin Abū Ṭālib dan orang-orang Shì'ah yang mengikutinya.

Abdurraḥmān bin A b̄ū Bakar al-Suyūtị, al-Durr al-Manthūr (Beirut: Dār al-Fikr), tth., vol. VIII, 589.

${ }^{23}$ Muhammad al-Musawi, Mazhab Pecinta Keluarga Nabi Kajian Al-Quran dan Sunnah, 604.

${ }^{24}$ Hal serupa terjadi pada masalah perempuan yang paling utama, apakah Khadijah atau $\overline{\mathrm{A}}$ 'ishah. Riwayat-riwayat yang ada bisa dipahami sebagai keunggulan salah satu di antara keduanya atas yang lain, sebagaimana salah satu dari mereka dinilai sebagai perempuan yang paling dicintai Rasulullah. Perdebatan ini ada di internal kalangan Sunni, sebagaimana hal ini juga terdapat di kalangan Shi' ah.

25 Dalam sebuah hadis, nabi berpesan sebanyak tiga kali, "keluargaku...aku ingatkan kalian (untuk berbuat baik) terhadap keluargaku”. Pesan ini diucapkan sebanyak tiga kali.

Muslim bin al-Hajjāj, Bab "Min Faḍa'il 'Ali”, Sahịh Muslim, vol. IV, 1873.

Dalam konteks zakat, ahlul bayt adalah keturunan Hāshim dan 'Abdul Muṭallib, sementara dalam konteks doa, ia dimaknai seluruh umat Islam. pengkhususan ahlul bayt sebagai 'Ali dan keturunannya, biasa digunakan dalam diskursus teologi.

${ }^{26}$ Firman-Nya, “...Sesungguhnya Allah menghendaki menghilangkan 'rijs' dari kalian wahai ahlul bayt, dan menyucikan kalian dengan kesucian yang sebenarbenarnya". 
yang bersamanya dalam sorban itu adalah ahlul baytnya. ${ }^{27}$ Para ulama sepakat akan keshahihan riwayat ini, ${ }^{28}$ yang belakangan dikenal dengan nama "hadis kisā".

Keutamaan dan kemuliaan yang diberikan kepada 'Ali bin Abū Ṭālib, diberikan juga kepada keturunannya. Keutamaan ini menjadi penguat keyakinan Shi' ah bahwa ia adalah orang yang paling berhak menjadi pemimpin umat Islam paska kemangkatan Rasulullah, bukan Abū Bakar dan dua khalifah setelahnya. Hal ini juga, menurut mereka, yang menjadi pertimbangan utama bagi Rasulullah dalam menetapkan 'Ali sebagai penggantinya, yang diteruskan oleh keturunannya. Dalam hal ini, Shī'ah memahami secara kontekstual ayatayat al-Quran dan hadis-hadis tentang orang-orang yang beruntung dan mulia sebagai 'Ali bin Abū Ṭālib, keluarganya, dan orang-orang yang mencintai mereka (yaitu Shi' ah)

Bagi sebagian pengikut Shì'ah, imāmah itu sama dengan nubuwah. Dua belas imam yang mereka nilai ma’sūm (terjaga dari dosa dan kesalahan) kedudukannya lebih mulia dari pada seluruh makhluk hingga nabi-nabi umum bukan nabi khusus yaitu Rasulullah Muhammad. ${ }^{29}$ Keyakinan ini dibangun dari aksiomatik akan banyaknya jumlah nabi dan rasul, dan mereka memiliki beban tugas yang berbeda. Menurut Shi' 'ah, nabi-nabi sebelum Rasulullah Muhammad diutus hanya untuk satu kaum, yang terkadang jumlahnya sedikit. Sementara Rasulullah Muhammad diutus untuk seluruh manusia (dan jin) dimulai sejak dakwah islamiyah disampaikan hingga hari Kiamat. Tugas Rasulullah ini kemudian diemban oleh para imam yang dalam perspektif Shi' ah lebih berat dari tugas nabi-nabi (selain Rasulullah), sehingga pantaslah jika para imam dinilai lebih mulia dari nabi-nabi tersebut. ${ }^{30}$ Pada poin keharusan memuliakan keturunan nabi Muhammad, Sunni dan Shì'ah bersepakat. Namun pada poin imam lebih mulia dari nabi, dua sekte ini berbeda pendapat.

${ }^{27}$ Ismā'il bin 'Umar bin Kathïr al-Dimishqi, Tafsir Ibn Kathïr atau Tafsir alQur'ān al-'Azīim (Beirut: Dār al-Kutub al-'Ilmiah, 1419 H.), cet. I, vol. VI, 366.

${ }^{28}$ Muhammad bin 'Umar bin al-Hasan Fakhruddin al-Rāzí, Mafătịh al-Ghayb (Beirut: Dār Ihyyā al-Turāth al-`Arabi, 1420 H.), cet. II, vol. VIII, 274.

${ }^{29}$ Muhammad al-Musawi, Mazhab Pecinta Keluarga Nabi Kajian Al-Quran dan Sunnah, 174-175.

${ }^{30}$ Shi'ah mengajukan pertanyaan retoris: Apakan nabi yang diutus kepada 100 orang sama mulianya dengan nabi yang diutus kepada 1.000.000 orang? Apakah nabi yang masuk kategori ulul 'azmi sama mulianya dengan nabi yang bukan ulul 'azmi? Apakah Rasulullah Muhammad sama mulianya dengan nabi yang ada sebelum beliau? Apakah dosen sama kedudukannya dengan guru taman kanak-kanak?

Muhammad al-Musawi, Mazhab Pecinta Keluarga Nabi Kajian Al-Quran dan Sunnah, 176. 
Dalam memahami entitas imāmah sebagai kelanjutan nubuwah (kenabian), Shī'ah melakukan penafsiran secara kontekstual terhadap ayat-ayat al-Quran dan hadis. Shi' 'ah memaknai mereka di luar zahir ayat, dan menakwilkannya di luar pemaknaan kebahasaan.

\section{B. Wașiyat Ghādir Khūm}

Konsep imāmah yang dimiliki Shī'ah, pondasi awalnya adalah keyakinan bahwa Rasulullah menunjuk 'Ali bin Abū Ṭālib sebagai penerusnya memimpin umat Islam, dan bahwa pemimpin kaum muslimin haruslah menunjuk orang yang akan menggantikannya. Penunjukan ini, menurut Shi'ah, terabadikan dalam riwayat yang disebut hadis wașiyat atau hadis Ghādir Khūm.

Shi' ah Ja'fariyah berpendapat bahwa penetapan khilāfah bagi 'Ali bin Abū Tăalib berdasarkan wasiat yang diberikan Rasulullah kepadanya pada hari Ghādir Khūm tanggal 18 Dzulhijjah. Bagi sekte Ja'fariyah, Rasulullah tidak mungkin melupakan imāmah yang menjadi salah satu Rukun Iman, ${ }^{31}$ sementara Allah telah menyempurnakan Agama-Nya dan Rasulullah telah menyampaikan khutbah wada' (pamitan) di hadapan shahabat-shahabatnya. ${ }^{32}$

Ibn Numair bercerita kepada kami dari Abdul Malik, dari Abdurraḥmān al-Kindi dari Zadhān Abū 'Umar, ia berkata, "Saya mendengar 'Ali di alRaḥbah bertanya kepada orang-orang: Siapakah yang menyaksikan Rasulullah pada hari Ghādir Khūm mengatakan sesuatu? Maka tiga orang berdiri dan menyatakan mendengar Rasulullah bersabda: Siapa yang menjadikan diriku (Rasulullah) sebagai pemimpin baginya, maka "Ali adalah pemimpin baginya.",33 Masih ada beberapa riwayat lain yang serupa. Ali Ahmad al-Salus menyatakan sanad hadis itu kualitasnya dhaif, tetapi matannya shahih karena adanya banyak riwayat yang mendukungnya. Bahkan menurut sementara orang, riwayat ini bersifat masyhur ${ }^{34}$ dan mutäwatir. ${ }^{35}$

31 Ada perbedaan substansial terkait Rukun Iman dalam terminologis Sunni, dengan Rukun Iman menurut Shi'ah. Menurut Sunni, Rukum Iman adalah keimanan kepada Allah, malaikat, kitab-kitab yang diturunkan oleh Allah, rasul-rasul-Nya, hari Kiamat, dan qadha dan qadar. Sementara menurut Shi'ah, seseorang disebut beriman ketika ia percaya kepada Tauhìd, 'Adālah (keadilan), Nubuwah (kenabian), Imāmah, dan Ma'ad (Kiamat). Mu'tazilah juga memiliki Rukun Iman yang berbeda dari Sunni dan Shi' ah, yaitu Tauhid, 'Adl (keadilan), al-Wa'd wa al-Wa'ìd (janji dan ancaman), alManzilah Bayn al-Manzilatayn, dan Amar Ma'ruf Nahi Munkar.

${ }^{32}$ Ali Ahmad al-Salus, Imamah dan Khilafah dalam Tinjauan Syar'i, 122.

${ }^{33}$ Ali Ahmad al-Salus, Imamah dan Khilafah dalam Tinjauan Syar'i, 147.

${ }^{34}$ Dalam disiplin Ilmu Hadis, kata "Masyhur" memiliki dua difinisi: Pertama hadis yang populer dan dikenal oleh masyarakat umum. Kedua, hadis yang memiliki jalur transmisi sanad yang jumlahnya antara 3 sampai 9. Definisi pertama tidak terkait dengan 
Ada sedikit perbedaan substansif terkait riwayat yang dimiliki Shī'ah dengan riwayat yang beredar di kalangan Sunni. Kedua mazhab ini menerima riwayat bahwa 'Ali bin Abū Ṭālib adalah mawlā bagi kaum muslimin, namun di kalangan Sunni tidak ada penambahan 'Ali adalah wasiatku dan khalifah setelahku" sebagaimana yang diterima oleh Shi'ah. Tambahan dalam riwayat ini yang menjadi dasar keyakinan bahwa kepemimpinan umat Islam itu sifatnya penunjukan dari Rasulullah.

Perlu diingat, bahwa hadis yang memiliki kualitas sanad baik (ṣahịh atau hasan) memerlukan kajian matan (isi hadis) sebelum ia menjadi hujjah. Dari sini sebenarnya polemik itu muncul, tepatnya pada pemaknaan "mawlā" yang dalam behasa Arab memiliki banyak arti, dan apakah arti-arti itu tepat jika diasumsikan sebagai penunjukkan 'Ali sebagai khalifah atau hanya sebatas penjelasan keutamaan dirinya. Sunni dan Shi'ah sama-sama menilai 'Ali bin Abū Ṭālib sebagai sosok shahabat yang memiliki keutamaan yang luhur.

Masalah yang kemudian muncul adalah keabsahan khilafah Abū Bakar, 'Umar dan 'Uthmān. Karena jika khilafah memang telah ditetapkan untuk 'Ali, maka ketiga khalifah itu tentu tidak memiliki legalitas dan legitimasi, padahal sejarah mencatat pembaiatan yang dilakukan 'Ali bin Abū Ṭālib terhadap ketiganya. Seandainya memang penunjukkan itu tidak sah, maka 'Ali yang terkenal memiliki keberanian tentu akan menuntut apa yang menjadi hak dan kewajibannya. Terjadinya peristiwa Saqifah Bani Sāidah juga merupakan indikator bahwa klaim penunjukkan 'Ali bin Abū Tâalib merupakan hal yang dibuat-buat, pasalnya kalaulah penunjukkan itu benar ada niscaya para shahabat tidak meributkan siapa shahabat yang menjadi khalifah pasca kemangkatan Rasulullah.

Adanya keterlambatan 'Ali bin Abū Ṭālib dalam membaiat Abū Bakar, dijelaskan sendiri olehnya, "Sesungguhnya kami mengerti keutamaanmu dan sesuatu yang diberikan Allah kepadamu. Kami tidak akan mampu mengungguli kebaikan yang diberikan Allah kepadamu. Namun kamu tidak bermusyawarah

shahih tidaknya sebuah hadis, karena hadis yang popular bisa jadi kualitasnya dhaif atau bahkan palsu. Sementara definisi kedua berkaitan dengan keshahihan sebuah hadis.

${ }^{35}$ Ali Ahmad al-Salus, Imamah dan Khilafah dalam Tinjauan Syar'i, 151.

Ibnu Hajar menegaskan bahwa hadis "man kuntu mawlahu fa "Ali mawlahu" diriwayatkan oleh banyak mukharrij semisal al-Tirmidzi dan al-Nasa'i dengan jalur periwayatan (sanad) yang banyak. Ibnu Hajar tidak menyampaikan riwayat dengan penambahan kalimat "Ali adalah wasiyatku" sebagaimana yang ada dalam riwayat Shi'’ah.

Aḥmad bin 'Ali bin Ḥajar al-"Asqalāni, Fatḥ al-Bārī Sharḥ Sahịị al-Bukhāri (Beirut: Dār al-Ma’rifah, 1379 H.), vol. VII, 74. 
kepada kami tentang urusan ini, sedangkan kami sebagai kerabat Rasulullah memiliki bagian di dalamnya" 36

Hal yang menjadi titik temu antara Sunni dan Shī'ah adalah kesepakatan dalam konsep keimanan terhadap kenabian Rasulullah. Hanya saja Sunni tidak mengakui kontinuitas wahyu Tuhan atas para imām-imām yang ma'shum, atau yang dikenal sebagai konsep pewarisan kepemimpinan. ${ }^{37}$

Shỉ'ah melakukan penafsiran kontekstual pada hadis Ghādir Khūm, yaitu dengan cara memaknai kata "mawlā" sebagai pemimpin yang secara khusus ditunjuk oleh Rasulullah sebagai pengganti darinya. Pemaknaan kontekstual ini juga dilakukan ketika makna "“Ali bin Abū Ṭālib mawla Rasulullah” dijadikan legitimasi kepemimpinan keturunan 'Ali bin Abū Ṭālib.

\section{Manzilah Ali bin Abu Thalib}

Dalam sebuah hadis, manzilah (kedudukan) 'Ali bin Abū Ṭālib terhadap Rasulullah seperti kedudukan nabi Hārūn terhadap nabi Mūsāa. ${ }^{38}$ Hadis ini dikenal sebagai hadis "manzilah".

Shi' ah menjadikan hadis manzilah sebagai dalil kekhalifahan 'Ali bin Abū Ṭālib, karena kedudukan yang disandarkan kepadanya ini tidak dimiliki oleh siapapun selainnya sehingga ia adalah orang yang paling berhak menjadi khalifah setelah Rasulullah, sebagaimana Hārūn menjadi khalifah bagi Mūsā saat beliau melakukan miqät. ${ }^{39}$ Sunni menolaknya alur nalar seperti ini. ${ }^{40}$

${ }^{36}$ Ali Ahmad al-Salus, Imamah dan Khilafah dalam Tinjauan Syar'i, 153.

37 Manzooruddin Ahmed, al-Nazariyāt al-Siyāsiyah al-Islāmiyah fi al-'Assr alHadith; al-Nazariyah wa al-Tatbiq , 46.

38 Al-Bukhāri, Bab "Manāqib 'Ali bin Abū Ṭālib”, Saḥịh al-Bukhāri, vol.V, 19; Muslim, Bab "Fadāil 'Ali bin Abū Ṭālib, Sahịị Muslim, vol. IV, 1870.

${ }^{39}$ QS. Al-A'rāf ayat 142.

${ }^{40}$ Menurut al-Nawawi, hadis manzilah ini dipahami oleh kaum Rāfiḍah, Imāmiah, dan seluruh aliran dalam Shì' ah sebagai dalil penunjukan Rasulullah kepada 'Ali bin Abū Țālib sebagai khalifah beliau. Kemudian pengikut Shī'ah sendiri berbeda pendapat terkait shahabat yang menerima kekhalifahan Abū Bakar, 'Umar bin al-Khațāb, dan 'Uthmān bin 'Affān. Sebagian mereka ada yang mengkafirkan seluruh shahabat termasuk 'Ali bin Abū Țâlib karena ia tidak mau memperjuangkan haknya dan justru ikut membaiat tiga khalifah yang telah merampas haknya. Pendapat ekstrim dari Rāfiḍah ini tentunya salah sebab seluruh umat Islam menjadi kafir karenanya. Shỉ'ah Imāmiah sendiri hanya menghukumi salah (khatha) tidak kufur.

Masih menurut al-Nawawi, hadis ini disabdakan Rasulullah saat menetapkan 'Ali sebagai pengganti sementara beliau di Madinah selama perang Tabuk. Hadis ini tidak bisa dipahami sebagai pengangkatan Ali sebagai khalifah setelah Rasulullah mangkat.

Yahyā bin Sharaf al-Nawawi, Sharḥ Șậịh Muslim, (Beirut: Dār Ihyā al-Turāth al'Arabi, 1392 H.), cet. II, vol. XV, 174. 
Secara tekstual, hadis manzilah bisa dimaknai keutamaan 'Ali bin Abū Tāalib. Secara tekstual juga, hadis ini menunjukkan kelayakan dirinya untuk memegang tampuk kepemimpinan tertinggi umat Islam. Namun jika hadis ini digunakan sebagai dalil ketidakabsahan khalifah selain 'Ali bin Abū Ṭālib, maka pemaknaan seperti ini sudah keluar dari teks dan konteksnya, karena tidak ada kata dan ungkapan yang menunjukkah hal itu.

\section{Thaqalayn}

Rasulullah meninggalkan dua pusaka (peninggalan), yaitu al-Quran dan keturunan beliau ( 'itratî̀) yang dinamai thaqalayn. Siapapun yang berpegang kepada thaqalayn, dirinya tidak akan tersesat. ${ }^{41}$ Dalam riwayat lain disebutkan bahwa dua pusaka tersebut adalah al-Quran dan sunnah Rasulullah. ${ }^{42}$ Kedua variasi riwayat hadis ini, kualitasnya sama-sama shahih.

Penamaan hadis "thaqalayn" sendiri berasal dari riwayat "Ali bin Abū Ṭālib bahwasanya Rasulullah menyatakan dirinya akan diambil (wafat) dan beliau meninggalkan thaqalayn, yaitu al-Quran dan ahlul bayt. ${ }^{43}$ Menurut Shi'ah, konsekuensi dari berpegang kepada thaqalayn adalah mengangkat mereka sebagai pemimpin umat, karena pemimpin haruslah memberi petunjuk, dan ahlul bayt adalah petunjuk bagi umat Islam.

Pemaknaan tekstual dari hadis thaqalayn adalah bahwa 'Ali bin Abū Ṭālib dan keturunannya merupakan orang-orang yang bisa dijadikan rujukan dan pedoman oleh umat Islam. Hadis thaqalayn dengan lugas mempararelkan alQuran dengan ahlul baytsebagai dua pusaka nabi Muhammad untuk umatnya.

Secara tekstual hadis ini juga bisa dimaknai sebagai anjuran memprioritaskan mereka dalam pemilihan khalifah atau imām. Namun pemaknaan hadis ini sebagai dalil ketidakabsahan ketiga khalifah sebelum 'Ali bin Abū Tạalib merupakan hal yang perlu diperdebatkan.

${ }^{41}$ Muhammad bin Issā al-Tirmidhī, Bab "Manāqib Ahl Bayt al-Nabi", Sunan alTirmidhī (Mesir: Shirkah Maktabah wa Maṭba'ah Muștafāa al-Bābi al-Hālabi, 1975), cet. II, vol. V, 662.

${ }^{42}$ Muḥammad bin Abdullāh al-Ḥākim al-Naysābūri, al-Mustadrak 'Alā al-Ṣaḥịhayn (Beirut: Dār al-Kutub al-'Ilmiah, 1990), cet. I, vol.I, 172.

43 Al-Haythami menilai hadis thaqalayn dari jalur al-Bazzār kualitasnya dhaif karena di dalam sanadnya ada perawi yang bernama al-Ḥārith, sementara dari jalur lainnya semisal al-Ṭabräni kualitasnya shahih. Shì'ah menilai hadis tsaqalayn bukan hanya shahih, namun juga mutawatir mengingat ada 20 shahabat yang meriwayatkannya, dan periwayatan itu masih terjaga.

A. Syarafuddin al-Musawi, Dialog Sunnah Syiah, 39. 


\section{E. Kewajiban Memiliki Imām}

Dalam surah al-Nisa ayat 59, Allah Ta'ala memerintahkan umat Islam untuk taat kepada-Nya, taat kepada Rasulullah, dan kepada ulul amri. ${ }^{44}$ Tidak ada perbedaan antara Sunni dan Shi' ah dalam kewajiban mengangkat pemimpin umat Islam karena akal sehat menyatakan bahwa manusia bukan makhluk soliter yang bisa mencukupi kehidupannya sendiri. ${ }^{45}$ Adanya pemimpin akan memastikan keberlangsungan kehidupan umat Islam terjaga, dan ajaran Agama bisa dijalankan dengan baik.

Mengangkat imām bukan semata didasari nalar logika, namun juga ada perintah dari Rasulullah dalam sabdanya, "Siapa yang mati tanpa memiliki imām, maka ia mati dalam keadaan jahiliyah". ${ }^{46}$ Bagi kaum Shì'ah kewajiban memiliki imām ini berlaku selamanya.

Shi' ah memahami imām sebagaimana dimaksudkan dalam hadis di atas sebagai sosok manusia yang menjadi pemimpin umat Islam. Pemaknaan tekstual ini sebenarnya dimengerti oleh kelompok Sunni. Namun penetapan imām-imām Shì'ah sebagai sosok pemimpin definitif yang dimaksudkan oleh Rasulullah, sudah bukan lagi pemaknaan tekstualis, karena sudah ada bias teologis dan nampak jelas justifikasi atas preferensi politisnya.

Sunni memahami hadis ini secara kontekstual bahwa setiap orang Islam harus memiliki imām yang dijadikan pedoman dan acuan dalam menjalani hidupnya. Namun imām tersebut bukanlah sosok manusia melainkan al-Quran. Bahwa dalam sebuah komunitas harus pemimpin dan pemimpin itu harus ditaati, merupakan hal yang disepakati dua sekte ini, namun perbedaan penafsiran teks antara tekstualitas dan kontekstualitas menghasilkan perbedaan hasil tafsirannya.

Terkait sanksi bagi orang yang enggan taat kepada imāmnya, Shī'ah bersikap tekstualis dengan menjadikan doktrin imāmah sebagai salah satu Rukun Iman. Bagi sebagian besar Shi'ah, mengingkari imām-imām (yang berjumlah 12) sangat mempengaruhi keimanan seseorang. Sementara Sunni memahami kontekstual frasa "mati dalam keadaan jahiliyah" sebagai dosa

44 "Wahai orang orang yang beriman, taatlah kalian Allah, taatlah kalian kepada Rasulullah dan kepada ulul amri..."

${ }^{45}$ O. Hashem, Syi'ah Ditolak Syi'ah Dicarai, 335.

${ }^{46}$ Muhammad bin Hibbān al-Bustīi, Sahịh Ibn Hibbān (Beirut: Muassasah alRisālah, 1993), cet. II, vol. X, 434.

Dalam pemahaman yang mainstream dalam tradisi Sunni, ungkapan "mati dalam kondisi jahiliyah" diartikan sebagai dosa besar, bukanlah kekufuran. Ungkapan ini masuk dalam kategori larangan yang sangat berat. 
besar. Pemaknaan Sunni didasarkan beberapa riwayat yang juga menggunakan ungkapan "mati jahiliyah" namun bukan bermakna kufur.

\section{Penafsiran Tekstual dan Kontekstual}

Penafsiran tekstual sering dipadankan dengan kata "nash" dalam bahasa Arab, sementara kontekstual diterjemahkan sebagai siyāq. Dua pola penafsiran ini menjadi salah satu faktor yang dominan atas munculnya keragaman tafsir. Dalam beberapa kasus, keragaman tafsir menjadi pemicu pertikaian internal umat Islam sebagaimana terjadi pada kasus Sunni dengan Shi' ah. Namun adanya keragaman tafsiran teks bisa jadi membawa anugerah, di mana umat Islam memiliki pilihan-pilihan.

Karakteristik penafsiran tekstual adalah keterikatan dengan makna harfiah kebahasaan (literal). Lain halnya dengan penafsiran kontekstual yang menggunakan pendekatan non kebahasaan sebagai alat bantu dalam menafsirkan seperti kondisi sosial masyarakat saat teks turun (disabdakan), sabab nuzul ayat, dan ideologi.

Shi'ah banyak menggunakan penafsiran kontekstual pada ayat-ayat dan hadis tentang sosok-sosok manusia mulia. Mereka memahami ayat-ayat dan hadis tersebut sebagai dalil kelayakan 'Ali bin Abū Ṭālib dan keturunannya untuk menjadi pemimpin umat Islam. Penafsiran kontekstual mereka lakukan dengan mempertimbangkan ideologi mereka. Ideologi ini juga menjadi alasan utama mereka saat melakukan penafsiran tekstual. Apa yang dilakukan Shï'ah juga merupakan hal yang lumrah dilakukan oleh Sunni dan sekte lain. Bahwa penafsir teks akan senantiasa memiliki pilihan untuk melakukan penafsiran tekstual dan kontekstual.

\section{Penutup; Kalimah Sawa'Sunni-Syi'ah}

Al-Quran surah al-Nisā ayat $1,{ }^{47}$ Yünus ayat $99,{ }^{48}$ dan Hūd ayat $118^{49}$ menjelaskan bahwa perbedaan dan keragaman merupakan sunnatullah dan kodrat penciptaan manusia. Hal senada juga dikesankan dalam ayat 213 surah al-Baqarah yang, menurut AA Sachedina, memunculkan 3 fakta, yaitu: Kesatuan umat manusia di bawah satu Tuhan, kekhususan agama-agama yang

47 "Wahai manusia, takutlah kalian kepada Tuhan kalian yang telah menciptakan kalian dari satu nafs (jiwa), dan Dia menciptakan darinya (nafs tadi) pasangannya dan dari kduanya tersebarlah laki-laki dan perempuan..."

48 "Jika Tuhanmu menghendaki maka seluruh orang yang di bumi akan beriman"

49 "Jika Tuhanmu menghendaki maka Dia jadikan seluruh manusia satu umat. Dan mereka senantiasa berselisih" 
dibawakan oleh para nabi, dan peranan wahyu (kitab suci) dalam mendamaikan perbedaan di antara umat beragama. ${ }^{50}$

Perbedaan dan keragaman pendapat tidak hanya ditemukan dalam Islam, namun juga dalam agama-agama lain. ${ }^{51}$ Sunni, Shỉ'ah, dan sekte-sekte (mazhab) lainnya dalam Islam, juga memiliki keragaman pendapat yang terdapat dalam internal sekte mereka. ${ }^{52}$ Menganggap Shì'ah sebagai sebuah "kodek" doktrin yang tunggal, tentunya melawan fakta dan ahistoris.

Di dalam Shi'ah ada beberapa aliran seperti Imāmiyah, Zaidiyah, Ismā'iliyah, Bātiniyah, Niz̄āriyah, Musta'liyah, Duqūqiyyah, Muqanna'ah, dan Ghulāt (Rāfiḍah), yang masing-masing memiliki pendapat yang tidak jarang saling bertabrakan.

Kaum Shi'ah Imamiyah menyatakan diri berlepas dari kaum Shï'ah Ghulāt seperti Sabāiyah, Khațābiyah, Ghurābiyah, dan Hulūliyah yang dinilai telah kafir dan wajib dijauhi. ${ }^{53}$ Di waktu yang sama, Shì'ah Imāmiyah menganggap Zaidiyah, Kisāniyyah, dan Qaddāhiyah sebagai faham dan sekte yang distorsif. ${ }^{54}$ "Ali bin Abū Țālib pernah berkehendak menghukum mati Abdullāh bin al-Saudā pimpinan kaum Sabāiyah, ${ }^{55}$ dan al-Bāqir melaknati kaum Ghulāt dan berpesan agar pengikutnya tidak menerima riwayat-riwayat mereka. Hal serupa juga dilakukan oleh para imam selanjutnya. ${ }^{56}$ Menyamakan aliranaliran yang ada dalam Shi' ah adalah kekeliruan epistemologis yang fatal. ${ }^{57}$

Kitab-kitab klasik tentang ilmu kalam (teologi), memasukkan Shī'ah dalam sekte-sekte Islam bersama Sunni, Mu’tazilah, dan Khawārij. Artinya,

50 AA Sachedina, Beda Tapi Setara; Pandangan Islam Tentang Non-Islam (The Islamic Roots of Democratic Pluralism) (Jakarta: Serambi Ilmu Semesta, 2004), cet. II, 50-51. 79.

${ }^{51}$ Muhammad Husayn Thabathaba'i, Islam Syiah Asal Usul dan Perkembangannya,

52 Menurut Muhammad al-Musawi, perbedaan yang ada dalam mazhab empat (Hanifiyyah, Malikiyyah, Syafi'iyyah, dan Hanbaliyyah) lebih banyak dibandingkan perbedaan yang ada antara Sunni dan Syi'ah.

Muhammad al-Musawi, Mazhab Pecinta Keluarga Nabi Kajian Al-Quran dan Sunnah, 423. Sunnah, 73.

${ }^{53}$ Muhammad al-Musawi, Mazhab Pecinta Keluarga Nabi Kajian Al-Quran dan

${ }^{54}$ Muhammad al-Musawi, Mazhab Pecinta Keluarga Nabi Kajian Al-Quran dan Sunnah, 90-93.

55 'Aiḍ bin Abdullāh al-Qarny, al-Bid'ah wa Atharuhā fì al-Dirāyah wa al-Riwāyah (Beirut: Dār Ibn Ḥazm, 2005), cet. II, 21.

${ }^{56}$ O. Hashem, Syi'ah Ditolak Syi'ah Dicari (Jakarta: Islamic Center Jakarta AlHuda, 2000), cet. III, 107.

57 Dalam surah al-Hasyr ayat 14 disebutkan “...wa tahsabuhum jami'an wa qulubuhum syatta” (Kamu mengira mereka bersama-sama padahal hati mereka berbedabeda). 
sekte-sekte ini masih berada di dalam naungan Islam, walaupun mereka dianggap telah melakukan bid'ah mufassiqah. ${ }^{58}$ Sikap yang lebih moderat ditunjukkan oleh ahli hadis (dalam tradisi Sunni) semisal al-Bukhāri dan Muslim yang menerima periwayatan dari perawi-perawi yang berasal dari golongan Shi' ah. ${ }^{59}$

Upaya mendisukusikan perbedaan-perbedaan bukan dalam rangka mengaburkan esensi dari pendapat-pendapat yang berseberangan, namun untuk mencari titik temu (kalimah sawā'). Dalam surah Alu Imrān ayat 64 ada seruan mencari titik temu antara Islam dengan ahlu kitab (Yahudi dan Nashrani). Seruan ini seyogyanya dijadikan pijakan awal dalam dialog Sunni-Shi'ah. Kajian kritis terhadap sebuah sekte atau pendapat haruslah didasari niat mencari kebenaran dan objektivitas, bukan prasangka dan sinisme. ${ }^{60}$

Sebagai bagian dari sejarah Islam, dua sekte ini tentunya memiliki kesamaan-kesamaan. Seandainya dari sepuluh konsepsi keagamaan yang ada pada Sunni dan Shi' ah terdapat tiga hal yang berbeda, maka tujuh kesamaan yang ada itu seharusnya dijadikan dasar kebersamaan. ${ }^{61}$

58 Dalam kajian ilmu hadis, bid'ah dalam masalah akidah dibagi menjadi dua: Mufassiqah yang periwayatannya diterima dengan persyaratan-persyaratan, dan mukaffirah yang periwayatannya ditolak secara mutlak. Bid'ah mufassiqah diberikan kepada mereka yang memiliki paham syubhat yang menjadikan mereka fasiq, sementara bid'ah mukaffirah adalah paham yang bertentangan dengan ushul (prinsip-prinsip dasar) Islam dan orang yang memiliki keyakinan ini divonis telah keluar dari Islam.

'Āid al-Qarni membagi bid'ah ke dalam lughawiyah dan 'amaliyah, mamduhah dan madhmumah, huda dan dalal, kubra dan șugra, mukaffirah dan mufassiqah, haqiqah dan idhafiyah, 'ibadiyah dan 'adiyah, basitah dan murakkabah, fi'liyah dan tarkiyah, 'amah dan khasah, serta i'tiqadiyah, qawliyah, dan 'amaliyah.

Lihat: Al-Fāsì, Hamdūn bin Abdurraḥmān, Nafhah al-Misk al-Dāri li Qārī alBukhāri (Beirut: Dār Ibn Hazm, 2008), cet. I, 138.

'Aiḍ bin Abdullāh al-Qarny, al-Bid'ah wa Atharuhà fì al-Diràyah wa al-Riwāyah, 47-55.

${ }^{59}$ S. Syarafuddin al-Musawi menyinyalir ada 100 perawi Syi'ah dalam kitab-kitab hadis Sunni. Al-Suyuthi memerinci perawi-perawi yang bukan Sunni yang periwayatannya diterima oleh al-Bukhari dan Muslim (atau salah satu di antara mereka), yaitu: pengikut Murjiah ada 14 orang, Nashbiyah 7 orang, Syi' ah 25 orang, Qadariyah 30 orang, Jahmiyah 1 orang, Harūriyah (Khawarij) 2 orang, Waqfiyah 1 orang, Qa'adiyah 1 orang. Totalnya ada 81 orang. Sementara menurut al-Qarni, jumlah mereka (rijāl alSahịhayn) ada 79 orang.

A. Syarafuddin al-Musawi, Dialog Sunnah Syiah, (Jakarta: Penerbit Mizan, 2001), cet. IX, 100. 140 .

Al-Fāsì, Ḥamdūn bin Abdurraḥmān, Nafḥah al-Misk al-Dārī li Qāri al-Bukhāri,

${ }^{60}$ O. Hashem, Syi'ah Ditolak Syi'ah Dicari, 26.

${ }^{61}$ O. Hashem, Syi'ah Ditolak Syi'ah Dicari, 12. 
Thabathaba'i berpendapat bahwa Sunni dan Shī'ah harus tetap percaya pada diri sendiri dan dasar-dasar tradisional mereka sebelum mereka membicarakan Islam. Bila mereka mau mengorbankan integritas mereka demi suatu titik temu yang tentunya akan mengurangi keutuhan masing-masing dan hanya akan merusak dasar-dasar tradisional yang telah memelihara dan menjamin vitalitas kedua mazhab ini selama berabad-abad. ${ }^{62}$

Mendiskusikan mazhab dan sekte dalam Islam, baik dalam masalah akidah maupun fiqh, kita seperti menonton film lama yang telah ditayangkan berulang kali. Masing-masing mazhab memiliki argumentasinya sendiri dengan disertai keyakinan akan kebenaran pendapatnya. Upaya mendialogkan keberagaman pendapat diharapkan bisa menguak kebenaran dan hidayah dengan cara yang damai, bukan kerancuan doktrinisasi agama atau pertikaian yang menumpahkan darah dan merusak kehormatan sesama umat yang menghadap qiblat dalam shalatnya. Allah Ta'ala A 'lam wa Huwa al-Hadi wa al-Musta'an.

\section{Daftar Pustaka}

Mushạ al-Qurān al-Karim

Abu Ghuddah, Abdul Fattah. Umarā' al-Mu'minin Fi al-Hadith. Aleppo: Maktabah al-Matbu'at al-Islamiyah, 1411 H., cet. I.

Alkaff, Achmad Zein. Export Revolusi Syi'ah Ke Indonesia. Pustaka alBayyinat, 2009, ttp., cet. I.

Ahmed, Manzooruddin. al-Nazariyat al-Siyāsiyah al-Islāmiyah fi al-'Aṣr alHadith; al-Nazariyah wa al-Tatbiqq. Karachi: Saad Publications, 1983.

Al-Bukhāri, Muhammad bin Ismā'īl. Saḥịh al-Bukhāri. Dār Ṭūq al-Najāh, 1422 H, cet. I.

Al-Fāsī, Ḥamdūn bin Abdurraḥmān. Nafḥah al-Misk al-Dārī li Qārì al-Bukhāri. Beirut: Dār Ibn Hazm, 2008., cet. I

Hamūr, Aḥmad Ibrāhīm. Shadzrāt min Tärīkh al-Daulah al-Umawiyah fi alSharq. Cairo: Dār al-Ṭibā'ah al-Muhammadiyah, 1998, cet. IV.

Hashem, O. Syi'ah Ditolak Syi'ah Dicari. Jakarta: Islamic Center Jakarta AlHuda, 2000, cet. III, 12.

Ibn Ḥajar, Aḥmad bin 'Ali al-'Asqalāni. Fatḥ al-Bārì Sharh Saḥịh al-Bukhāri.

Beirut: Dār al-Ma’rifah, 1379 H.

${ }^{62}$ Muhammad Husayn Thabathaba'i, Islam Syiah Asal Usul dan Perkembangannya, 6. 
Ibn Ḥibbān, Muḥammad al-Busti. Saḥịh Ibn Hibbān, Beirut: Muassasah alRisālah, 1993, cet. II.

Ibn Kathīr, Ismā'īl bin 'Umar al-Dimishqi. Tafsir Ibn Kathïr atau Tafsir alQurān al-'Ażìm. Beirut: Dār al-Kutub al-'Ilmiah, 1419 H., cet. I.

Al-Musawi, A. Syarafuddin. Dialog Sunnah Syiah. Jakarta: Penerbit Mizan, 2001, cet. IX.

Al-Musawi, Muhammad. Mazhab Pecinta Keluarga Nabi Kajian Al-Quran dan Sunnah. Bandung: Mpress, 2009, cet. III.

Muslim bin al-Ḥajāaj al-Naysābūri. Saḥịh Muslim. Beirut: Dār Ihyāa al-Turāth al'Araby, tth.

Al-Nawawi, Yahyā bin Sharaf. Sharh Șhịịh Muslim. Beirut: Dār Ihyāa al-Turāth al-'Arabi, 1392 H., cet. II.

Rahman, Andi. "Modus Suksesi Kepemimpinan Dalam politik Islam: Sebuah Pendekatan Sejarah". Dalam jurnal Mumtaz. Jakarta: Program Pascasarjana Institut PTIQ Jakarta, 2012, no. 2.

Al-Rāzì, Fakhruddin Muhammad bin 'Umar bin al-Ḥasan. Mafätīh al-Ghayb. Beirut: Dār Ihyāa al-Turāth al-'Arabi, 1420 H., cet. II.

Sachedrian, AA. Beda Tapi Setara; Pandangan Islam Tentang Non-Islam (The Islamic Roots of Democratic Pluralism). Jakarta: Serambi Ilmu Semesta, 2004 , cet. II.

-------. Kepemimpinan Dalam Islam Perspektif Syi'ah (The Just Ruler in Shi'ite Islam). Bandung: Penerbit Mizan, 1994, cet. II.

Al-Salus, Ali Ahmad. Imamah dan Khilafah dalam Tinjauan Syar'i. Jakarta, Gema Insani Press, 1997, cet. I.

Sjadzali, Munawir. Islam dan Tata Negara: Ajaran, Sejarah dan Pemikiran. Jakarta: Penerbit Universitas Indonesia (UI-Press), 1993.

Al-Suyūṭi, Abdurraḥmān bin Abū Bakar. al-Durr al-Manthūr. Beirut: Dār alFikr, tth.

Thabathaba'i, Muhammad Husayn. Islam Syiah Asal Usul dan Perkembangannya. Jakarta: Pustaka Utama Grafiti, 1993, cet. II.

Al-Tirmidzì, Muhammad bin 'Isā. Sunan al-Tirmidhi. Kairo: Shirkah Maktabah wa Maṭba’ah Muștafā al-Bābi al-Ḥalabi, 1975, cet. II.

Al-Qarni, 'Āị̣ bin Abdullāh. al-Bid'ah wa Atharuhā fi al-Dirāyah wa alRiwāyah. Beirut: Dār Ibn Hazm, 2005, cet. II.

Qiraati, Muhsin. Ushuluddin (Lesson From Al-Qur'an). Jakarta: Penerbit Cahaya, 2007, cetakan khusus. 